\title{
Analysis of Import Gate Out Service Using Control Chart in PT Terminal Petikemas Surabaya
}

\author{
Rafly Septianarta Putra ${ }^{1 *}$, Iis Dewi Ratih ${ }^{1}$
}

\begin{abstract}
Goods from abroad entering Indonesia must go through several stages of inspection. One of the final inspection stages of imported goods is through the import gate out of PT Terminal Petikemas Surabaya (PT TPS). Import Gate Out is the entry and exit access for each truck that will carry out activities in the area of PT TPS. The gate itself functions as a place to identify containers that will enter whether they are in accordance with the data and as a place of confirmation for the commanderer who will leave the port whether it has been completed and is in accordance with the existing procedures. In the import gate out process, there are operators in charge to ensure that the incoming or outgoing containers are in accordance with the existing system at PT TPS. In carrying out its duties, gate operators are expected to have the skills and speed to serve every container that will enter or leave PT TPS. To determine the extent of the performance duration of the gate operator PT TPS a research was conducted on the service time of the import gate out operator using descriptive analysis and control charts. This research was conducted using data collection techniques by observation. The results of this study indicate that the average transaction per day is $\mathbf{3 3 . 5}$ seconds.
\end{abstract}

Keywords - Descriptive, Control charts, Gate operator service performance duration

\section{INTRODUCTION}

I nternational trade is one of the economic and trade activities carried out by residents of a country with residents of other countries based on mutual agreement [1]. The dominant international trade is exports and imports. Exports are sales transactions of domestic goods and services. Meanwhile, imports are transaction activities for goods and services from abroad. Export-import activities usually begin through the trading port terminal. One of the major port terminals on the island of Java is PT Terminal Petikemas Surabaya which is located none other than in Surabaya. In carrying out export-import activities, PT Terminal Petikemas Surabaya has a gate or more commonly referred to as a gate. Gate is the entry and exit access for every truck that will carry out activities around PT Terminal Petikemas Surabaya. The gate itself functions as a place to identify containers that will enter whether they are in accordance with the data and as a place of confirmation for the commander who will leave the port whether it has been completed and is in accordance with the existing procedures.

Gate itself consists of 3 types of gates, namely export, import, and domestic, each gate is divided into two types of access, namely out (out) and out (out). Each gate has a gate officer who is usually referred to as a gate operator. The gate operator has the task of ensuring that the incoming or outgoing containers are in accordance with the existing system at PT Terminal Petikemas Surabaya. On the other hand, in carrying out its duties, the gate operator must have the skills and speed to serve every container that will enter or leave PT Terminal Petikemas Surabaya. This is used so that customers / customers get maximum service from each given performance. Often in the process, there is a traffic jam caused by the high number of trucks that do not match the performance carried out by the gate operator. This has attracted the view of customers who make transactions at PT Terminal Petikemas Surabaya. To find out the characteristics of the service time, a research was conducted on the work process carried out by the gate operator. The method used in this research is process descriptive analysis and $\mathrm{S}$ and XS control chart. The variable used itself is every process of service movement from each gate operator.

This research was conducted by observing one type of gate namely the exit gate (out) of imports. The reason for choosing an import exit gate as an object of research is due to congestion that often occurs and disrupts the process of field activities and is one of the gates that is semi-automatic. The purpose of this research is to achieve the maximum gate service process by observing and analysing the time of each gate operator who is currently working. This research is expected to be able to reduce congestion that often occurs at the Gate Out of imports.

\subsection{Data Exploration and Visualization}

The analysis used in data exploration used descriptive statistics. Descriptive statistics are methods related to the collection and presentation of a data set so as to provide useful information. Descriptive statistics are only related to describing or providing information about a data or condition, symptoms, or problem [2]. This research will use several analyzes, namely Mean. Tables, Barcharts, and Line charts.

Mean or what is called average or mean is the sum of all data divided by the number of data [2]. In this case the mean can be calculated when the data is quantitative. The formula used to find the average for

\footnotetext{
${ }^{1}$ Department of Business Statistics, Faculty of Vocational Studies, Institut Teknologi Sepuluh Nopember, Kampus ITS Sukolilo, Surabaya, 60111, Indonesia. E-mail: raflyseptian@gmail.com
} 
single data is in formula 1

$$
\bar{x}=\frac{\sum_{i=1}^{n} x_{i}}{n}
$$

Information:

$\mathrm{x}_{\mathrm{i}}=$ data

$\mathrm{n}=$ amount of data

Tables are collections of data arranged by rows and columns. These rows and columns are used to show the data related to them. Where the point of intersection between rows and columns is the data in question. Graph is a description of the dynamics of existing data (can go up, down, or up and down [2].

Line chart is the simplest type of chart because it only presents data on closing prices in a period that runs from time to time. We can choose the time period according to what we want, namely one minute, five minutes, fifteen minutes, thirty minutes, one hour, one day, one week, or one month [3].

Bar charts present data that is more complete than line charts. In a bar chart, we can see the opening price (open), closing price (close), the highest price (high), and the lowest price (low) of a commodity in a period from time to time. The open price is shown by a line going to the left and the close price is indicated by a line going to the right. The lower end is the lowest price and the upper end is the highest price [3].

\subsection{Random Test}

The Random Test is a series test to see randomness. The purpose of the series test is to determine whether there is a certain pattern in the data or whether the data is a random sample, then from the implementation of this run test 2 possibilities will be obtained, namely if the data is random (random) to the median then the data is homogeneous, whereas if the data has a tendency (trend) more than the median or below the median then the data is not homogeneous. The data assumptions available for the Run Test can be categorized into two mutually exclusive groups with $\mathrm{n}=$ total sample size, $\mathrm{n}_{1}$ $=$ number of observations in one group, $\mathrm{n}_{2}=$ number of observations of the other group. The procedure for the Run Test is as follows [4]

(1). Determining Hypotheses

$\mathrm{H}_{0}$ : Observational data have been taken randomly from a population.

$\mathrm{H}_{1}$ : Observational data have been taken from a nonrandom population.

(2). Sort the data from smallest to largest and then determine the median of the data.

(3). Counting the number of data that is smaller than the median $\left(\mathrm{n}_{1}\right)$ and the number of data that is greater than or equal to the median $\left(\mathrm{n}_{2}\right)$.

(4). Determine the test statistic, namely $r$

(5). Withdrawing a decision, Reject $\mathrm{H}_{0}$ if $\mathrm{r}<\mathrm{r}$ below and $r>r_{\text {above }}$, while failing to reject if $r>r d$ below with $r_{\text {bellow }}$ and $r_{\text {above }}$ are obtained from table $r$ for the series test.
(6). Draw a conclusion.

If $n_{1}$ and $n_{2}>20$ then use the formula to find ' $z$ ' as follows

$$
z=\frac{r-\left[\left\{\left(2 n_{1} n_{2}\right) /\left(n_{1}+n_{2}\right)\right\}+1\right]}{\sqrt{\frac{2 n_{1} n_{2}\left(2 n_{1} n_{2}-n_{1}-n_{2}\right)}{\left(n_{1}+n_{2}\right)^{2}\left(n_{1}+n_{2}-1\right)}}}
$$

\subsection{X-S Control Diagram}

A control chart is a map with an upper control limit (UCL / Upper Control Limit) and a lower control limit (LCL / Lower Control Limit), where the values of several statistical measures for a sample series of subgroups and a the center line which helps in showing the trend of the drawn values towards the control limit. One of the control charts is the XS control chart, this control chart is used to show he variability of the production process. This control chart is used when the sample size is large enough $(\mathrm{n} \geq 10)$, this control chart is also more sensitive when compared to the control chart R. Therefore, the appropriate control chart is the $\mathrm{X}$ and $\mathrm{S}$ diagram, where $\mathrm{S}$ is the root of sample variation $\left(S^{2}\right)$, with

$$
S^{2}=\frac{\sum_{i=1}^{n}\left(x_{i}-\bar{x}\right)^{2}}{n-1}
$$

If $\sigma^{2}$ known, then the control limits for the S2 diagram are:

$$
\begin{aligned}
& U C L=c_{4} \sigma+3 \sigma \sqrt{1-C_{4}^{2}} \\
& L C L=c_{4} \sigma+3 \sigma \sqrt{1-C_{4}^{2}}
\end{aligned}
$$

Meanwhile, if $\sigma$ unknown, it is estimated by the mean of sample standard deviations ( $\bar{S}$ ), so that if we know $\mathrm{m}$ preliminary samples each of size $\mathrm{n}$, and $\mathrm{Si}$ is the standard deviation of sample I then the estimation of $\sigma$ is [5]

$$
\bar{S}=\frac{1}{m} \sum_{i=1}^{m} S_{i}
$$

Thus the control limit for the $\mathrm{S}$ diagram is

$$
U C L=B_{4} \bar{S} \text { and } L C L=B_{3} \bar{S}
$$

As for the limit control diagram ${ }^{\bar{x}}$ is

$$
\begin{gathered}
U C L=\overline{\bar{x}}+A_{3} \bar{S} \\
L C L=\overline{\bar{x}}-A_{3} \bar{S}
\end{gathered}
$$

\subsection{Gate Out Import}

Gate has a meaning the entrance. The door is used to access a certain place. Import is the process of legally transporting goods or commodities from one country to 
another, generally in the trade process. The import process is generally the act of bringing goods or commodities from other countries into the country. Imports of goods generally require interference from customs in both the sending and receiving countries [6]. Based on these two definitions, it can be concluded that an import gate is an entrance to or from a place that is used as a storage for goods from trade from abroad.

\subsection{Duration}

The duration is explained to mean the length of time something lasts. Other sources explain that the intensity of a use can be measured based on duration. Duration is expressed in units of a certain time period (minutes or hours) [6].

\subsection{Process / Activity Description}

There is a definition of the process / activity being observed. The following is a description of the observation process.

(1) Truck to operator

The activity starts from the driver has finished provide customs documents to Customs until the driver goes to the operation gate.

(2) Drivers provide job slips, BAT, and ID cards

The activity starts with the driver giving a job Slip, BAT and, Id Card to Gate Operator accept Job Slips and Id Cards.

(3) The gate operator taped the id card.

The activity starts from the operator receiving an Id Card until doing tap Id with sound proof.

(4) The gate operator confirms.

The activity starts from the operator checking container number on the container until it clicks "Confirm" on the system.

(5) The driver takes an id card.

The activity starts with the operator providing an Id Card to the driver until the driver receives the Id Card

(6) The drivers exit the gate.

The activity starts with the driver receiving an Id Card until it exits the terminal to the backside container has crossed the Gate Out boundary

\section{METHOD}

\subsection{Data source}

The data source used in this study is primary data. Primary data is a data source that directly provides data to data collectors or data obtained directly by observing the object of research [8]. The data in this study were taken directly from February 23, 2020 to March 7, 2020 at PT Terminal Petikemas Surabaya. The data taken is 2815 data.

\subsection{Research variable}

The research variable is research material that is used as an analysis to solve problems. The research variable used in this study is to use the gate service duration by the gate operator. data variables can be presented in table 1 .

TABLE 1

RESEARCH VARIABLE

\begin{tabular}{clc}
\hline \hline Variable & \multicolumn{1}{c}{ Information } & Scale \\
\hline$X_{1}$ & $\begin{array}{l}\text { The duration of time the truck driver } \\
\text { reaches the operator }\end{array}$ & Ratio \\
$X_{2}$ & $\begin{array}{l}\text { The duration of time the driver } \\
\text { provides job slips, BAT, and ID } \\
\text { cards }\end{array}$ & Ratio \\
$X_{3}$ & $\begin{array}{l}\text { The duration of time that the gate } \\
\text { operator will tap the id card }\end{array}$ & Ratio \\
$X_{4}$ & $\begin{array}{l}\text { The duration of time the gate } \\
\text { operator confirms }\end{array}$ & Ratio \\
$X_{5}$ & $\begin{array}{l}\text { The duration of time the truck driver } \\
\text { takes the id card }\end{array}$ & Ratio \\
$X_{6}$ & $\begin{array}{l}\text { The duration of time the truck exits } \\
\text { the import gate out }\end{array}$ & Ratio \\
\hline \hline
\end{tabular}

\subsection{Data Structure}

The data structure is a form of framework from the data that will be processed or analyzed. The data structures used in this analysis are as follows

TABLE 2

RESEARCH DATA STRUCTURE

\begin{tabular}{|c|c|c|c|c|c|}
\hline \multirow{2}{*}{$\begin{array}{c}\text { Date } \\
\text { Observation }\end{array}$} & \multicolumn{4}{|c|}{$\begin{array}{c}\text { Observation process } \\
\text { (Total Time) }\end{array}$} & \multirow{2}{*}{$\begin{array}{c}\text { Total } \\
\text { Activity } \\
\text { Time }\end{array}$} \\
\hline & 1 & 2 & $\ldots$ & 6 & \\
\hline 1 & $x_{11}$ & $x_{12}$ & $\ldots$ & $x_{l n}$ & \\
\hline 2 & $x_{21}$ & $x_{22}$ & $\ldots$ & $x_{2 n}$ & \\
\hline$\vdots$ & $\vdots$ & $\vdots$ & $\ldots$ & $\vdots$ & $\vdots$ \\
\hline 14 & $x_{m 14}$ & $x_{m 14}$ & $\ldots$ & $x_{14}$ & $X_{i}$ \\
\hline
\end{tabular}

\subsection{Analysis procedure}

The research procedure is the flow carried out by the researcher to solve the problem. Conducted from the data collection process until conclusions were drawn. Following are the steps of this research from this research.

1) Collecting data by observing / observing activities per process at the import gate out of PT Terminal Petikemas Surabaya.

2) Perform data analysis using / average average of research results based on variables research.

3) Create visualization of data analysis results with use barchart, line chart, and tables.

4) Perform tests of normality and randomness assumptions

5) Create $S$ and XS Controls

6) Interpret the results of data analysis 
7) Draw conclusions and suggestions

\section{RESULTS AND DISCUSSION}

\subsection{Overall Activity Average}

The average overall apprenticeship activity is the average of one activity transaction during the observation. Explaining the average transaction time of all gate services by gate operators is 33 seconds. This shows that in one activity transaction, it takes 33 seconds.

The overall average time for activities is presented in table 4 as follows.

TABLE 4

AVERAGE PROCESS OF EACH ACTIVITY / DAY

\begin{tabular}{ccccccc}
\hline & \multicolumn{6}{c}{ Average Process of Each Activity Per Day } \\
& $\mathbf{1}$ & $\mathbf{2}$ & $\mathbf{3}$ & $\mathbf{4}$ & $\mathbf{5}$ & $\mathbf{6}$ \\
\hline 1 & 6.4 & 3 & 3.1 & 3.5 & 3.1 & 12.5 \\
2 & 8.2 & 3.3 & 3.3 & 2.1 & 2.1 & 11.3 \\
3 & 6.4 & 2.2 & 1.8 & 6.9 & 2.8 & 13 \\
4 & 6.8 & 1.9 & 1.8 & 6.2 & 2.4 & 14.8 \\
5 & 6.5 & 1.7 & 1.7 & 6.3 & 2 & 14.3 \\
6 & 6.6 & 1.9 & 2.2 & 6.3 & 2.3 & 16.3 \\
7 & 7.3 & 1.8 & 2.2 & 5.3 & 2.2 & 12.2 \\
8 & 6.1 & 1.8 & 2.2 & 6.9 & 2.1 & 16.6 \\
9 & 5.9 & 1.8 & 2.2 & 6.5 & 2.1 & 13.3 \\
10 & 5.6 & 1.6 & 2.2 & 6.6 & 2.2 & 13.7 \\
11 & 6 & 2 & 2.6 & 6.8 & 2.3 & 12.4 \\
12 & 5.8 & 2.3 & 2.9 & 7.3 & 1.8 & 13.4 \\
13 & 6.1 & 2.5 & 2.6 & 7.3 & 1.8 & 14.7 \\
14 & 6.2 & 2.2 & 2.9 & 6.4 & 6.4 & 15.7 \\
\hline \hline
\end{tabular}

\subsection{Average of Each Activity}

The daily average per process can be determined by calculating the average value of each process during the observation. There are 6 processes, so that the average per day per activity can be presented on the barchart as follows.

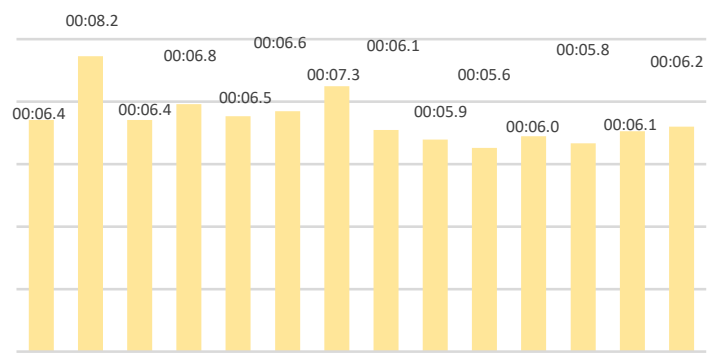

DAY 1 DAY 2 DAY 3 DAY 4 DAY 5 DAY 6 DAY 7 DAY 8 DAY 9 DAY 10DAY 11DAY 12DAY 13 DAY 14

Figure 1. Average of Truck Time to Operator

Figure 1 describes the average time for Driver activities to the gate operator during the fastest observation, which was 5.6 seconds on March 32020 (day 10), and the longest time was 8.2 seconds on February 24, 2020 (day 2).

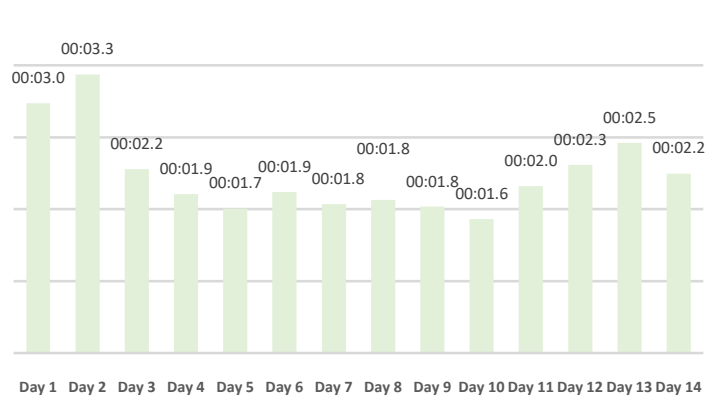

Figure 2. Average Driver giving Job Slips etc.

Figure 2 describes the average time for activities to provide job slips etc. During the fastest observation was 1.6 seconds on March 3, 2020 (day 10) and the longest time was 3.3 seconds on February 24, 2020 (day 2).

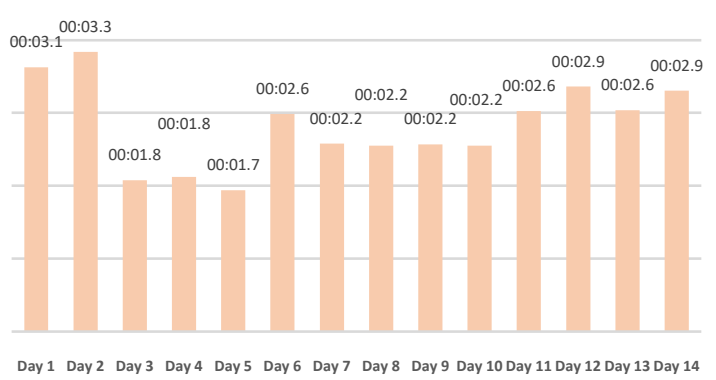

Figure 3. Average Time of Gate Operator Tap Id Card

Figure 3 describes the average time for the gate tap operator activity during the fastest observation, which was 1.7 seconds on 29 February 2020 (day 5) and the longest time was 3.3 seconds on 24 February 2020 (day 2).

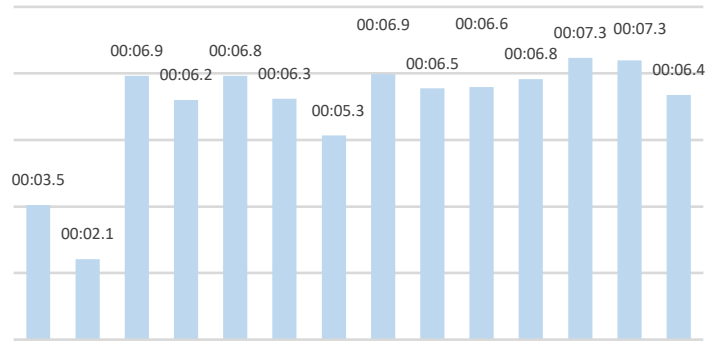

Day 1 Day 2 Day 3 Day 4 Day 5 Day 6 Day 7 Day 8 Day 9 Day 10 Day 11 Day 12 Day 13 Day 14

Figure 4 Average of Gate Operator Confirmation

Figure 4 describes the average time for gate confirm operator activities during the fastest observation, which was 2.1 on February 24, 2020 (day 2) and the longest time was 7.3 seconds seconds on March 5 -6, 2020 (day 12- day 13) 


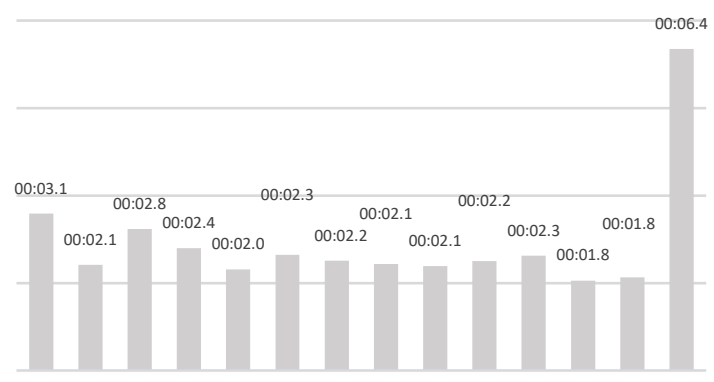

Day 1 Day 2 Day 3 Day 4 Day 5 Day 6 Day 7 Day 8 Day 9 Day 10 Day 11 Day 12 Day 13 Day 14

Figure 5. Average Average Driver taking Id Card

Figure 5 explains the average time for the activity to give Drivers to take the Id Card during the fastest observation, which is 1.8 seconds on March 5 and 6 2020 (day 12 -day 13) and the longest time is 6.4 seconds on March 72020 (day 14).

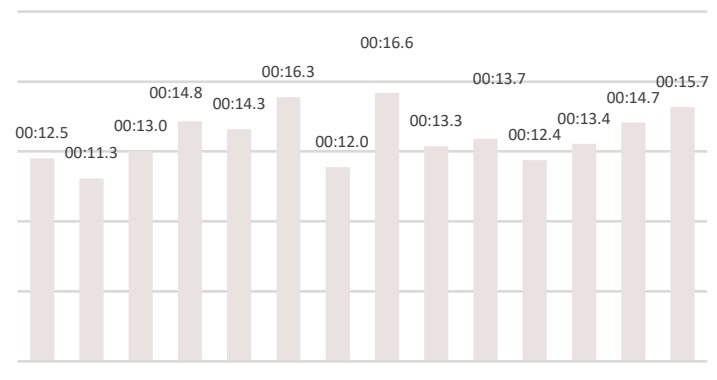

Figure 6. Average Truck Outtime

Figure 6 describes the average activity time Driver The truck headed for the gate operator during the observation, the fastest was 11.3 seconds on February 24 (day 2) and the longest time was 16.6 seconds on March 1, 2020 (day 8).

\subsection{Average Per Season}

Season or the season at PT Terminal Petikemas Surabaya is the density of transactions that occur within a certain period of time. Divided into two kinds of seasons, namely low season and peak season. Low season is a condition where transactions that occur at PT Terminal Petikemas have a large distance between transactions. Meanwhile, peak season is a condition where transactions that occur at PT Terminal Petikemas have a small distance between transactions. The following is a table and graph of analysis of the average per season.

TABLE 5

AVERAGE EACH SEASON IN SECONDS

\begin{tabular}{ccccccc}
\hline \hline Season & Process 1 & Process 2 & Process 3 & Process 4 & Process 5 & Process 6 \\
\hline $\begin{array}{c}\text { Low } \\
\text { Season }\end{array}$ & 6.1 & 1.9 & 2.3 & 6.6 & 2.2 & 13.4 \\
$\begin{array}{c}\text { Peak } \\
\text { Season }\end{array}$ & 5.4 & 2 & 2.5 & 6.9 & 2 & 13.4 \\
\hline \hline
\end{tabular}

Table 5 describes the time required for gate operators to perform services at the gate during the observation. It can be seen that there is a slight difference in service time. Where the service in the peak season is longer than the low season. For clarity, it can be presented in the form of a line chart as follows.

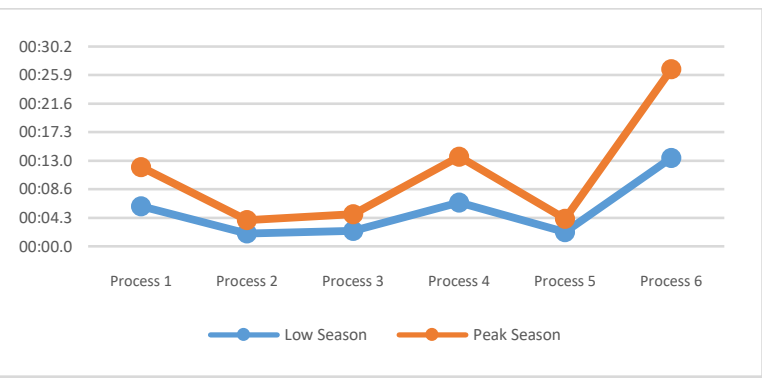

Figure 7. Line Chart Every Season in Seconds

Figure 7 is a line graph of the duration based on the season during the observation. Based on this graph, it can be seen that the low season and peak season tend to have the same pattern. Peak season has a longer average service than low season.

\subsection{Normal Distribution Test and Randomness}

Testing the assumptions of the nomal distribution is carried out to prove whether the service duration is normally distributed or not. Here are the results of the analysis.

Hypothesis

$\mathrm{H}_{0} \quad$ : Duration of service gate by the gate operator normally distributed

$\mathrm{H}_{1} \quad$ : Duration of service gate by the gate operator not normally distributed

Significant Level : $\alpha: 0.05$

Area of Rejection:Reject $\mathrm{H}_{0}$ if $\mathrm{P}$-value $<\alpha$ and reject $\mathrm{H}_{0}$ if $\mathrm{KS}>\mathrm{KS}$ Table

Test Statistics

$$
\text { TABLE } 6
$$

NORMAL DISTRIBUTION TESTING

\begin{tabular}{cc}
\hline \hline Pvalue & 0.976 \\
\hline Kolomogorov Smirnov & 0.296 \\
\hline \hline
\end{tabular}

The test statistics show that P-value value of 0.976 is greater than $\alpha$ and the KS value is smaller than the Table $\mathrm{KS}$, which means that $\mathrm{H}_{0}$ failed to be rejected. Thus, the duration of the import Gate Out service process is normally distributed. The following is the randomness test of the gate service duration data by the gate operator.

Hypothesis

$\mathrm{H}_{0} \quad$ : Duration of service gate by the gate operator has taken at random

$\mathrm{H}_{1} \quad$ : Duration of service gate by the gate operator not taken randomly

Significant Level : $\alpha: 0.05$

Rejection Area: Reject $\mathrm{H}_{0}$ if $\mathrm{P}$-value $<\alpha: 0.05$

Test Statistics

TABLE 7

RANDOMIZATION TESTING

\begin{tabular}{cc}
\hline Test & Score \\
\hline Mean & 31.95 \\
\hline Pvalue & 0.102
\end{tabular}

Based on the data in table 4, it can be seen that the $\mathrm{p}$ value of 0.102 is greater than alpha of 0.05 so that $\mathrm{H}_{0}$ fails to reject, which means the observational data has been taken randomly.

\section{5. $S$ and $X-S$ Control Charts}

The $S$ control chart is used to find out whether the lecture process in the Business Statistics department has 
been controlled or not. Based on the variability of lecture duration. The results of the analysis are as follows.

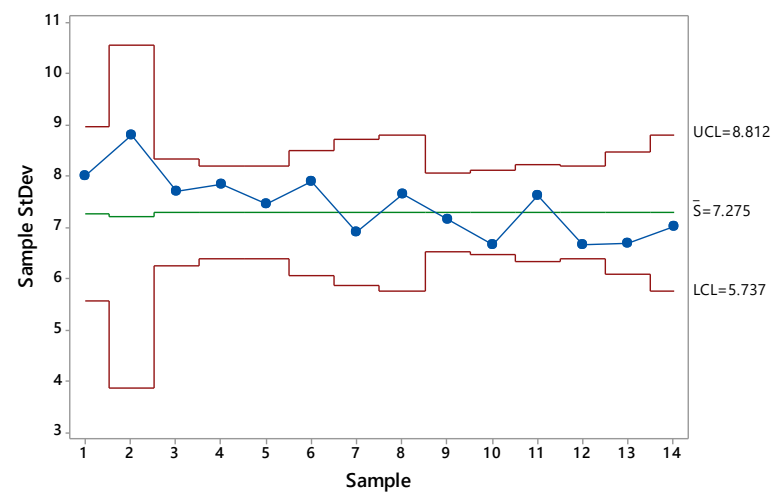

Figure 8. Control Map S Service Process

Figure 8 shows that none of the plots on the control chart $\mathrm{R}$ are out of control, so it can be said that the service process at the gate has been controlled statistically. $\bar{x}$ - S. Here is the analysis.

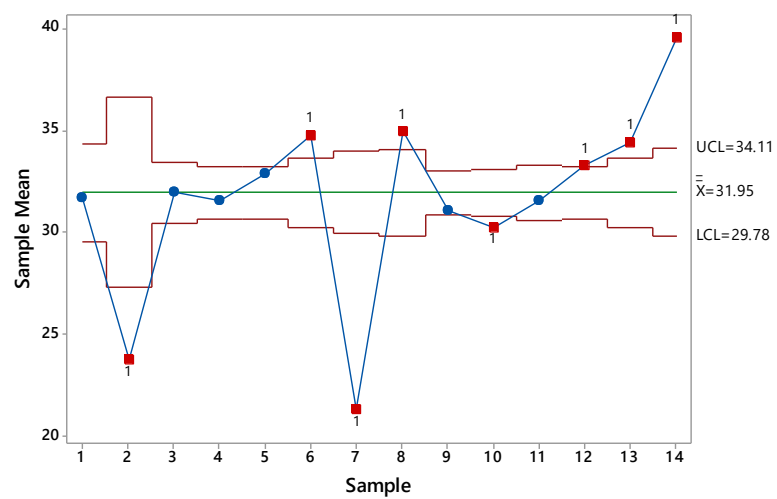

Figure 9. Control Map XS Service Process

Figure 9 explains that the plots on the control chart $\mathrm{X}$ are out of control so it can be said that the service process at the gate has not been controlled statistically. So it can be continued with a process capability analysis based on the capability index.

\subsection{Fishbone Service Process Diagram}

Fishbone diagram is used to determine the cause of process discrepancies. Here is fishbone of each process / activity of import Gate Out operator services.

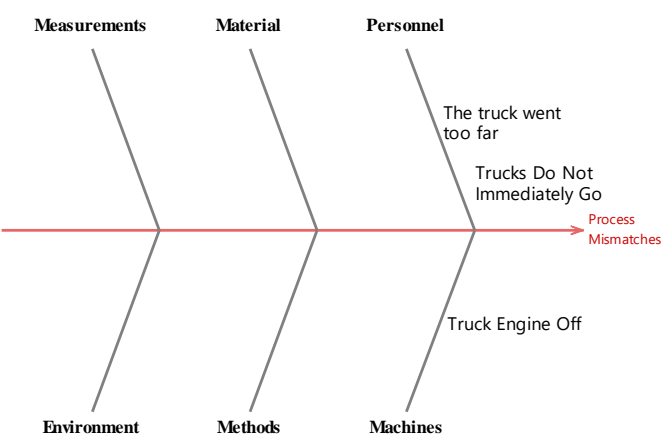

Figure 10. Fishbone First Process

Figure 10 explains the causes of the non-conformity of the process from the first process, namely the Driver process leading to the gate operator. It can be seen that the causes that occur can be caused by the driver who drives the truck beyond the gate operator post and the truck does not immediately go to the gate operator after the process at Customs is finished and there are problems with the truck engine suddenly turning off so that the driver needs to start up the engine.

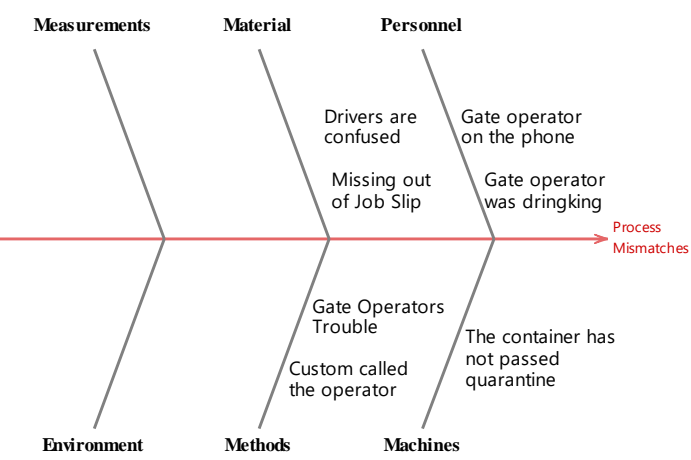

Figure 11. Fishbone of Second Process

Figure 11 explains the causes of the inadequacy of the second process, namely the Driver process providing job slips etc. It can be seen that the causes that occur can be caused by drivers who are confused about looking for job slips, etc., even losing job slips et al and gate operators who carry out activities outside of service but are still within reasonable limits of work, namely making calls. There is also a system error that has not confirmed the containers that have passed quarantine, the last is a call from the Customs when the truck is at the gate operator.

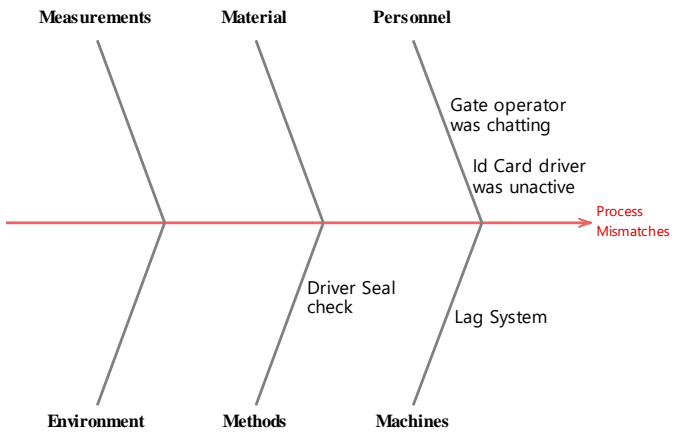

Figure 12. Fishbone Diagram Third Process

Figure 12 explains the causes of the inadequacy of the third process, namely the gate tap operator process Id. It can be seen that the causes that occur can be caused by the chatting operator and the presence of a driver whose Id Card period has ended and a container whose seal no is not inputted, so the driver has to go down and check it to be informed to the gate operator. Here is fishbone process four. 


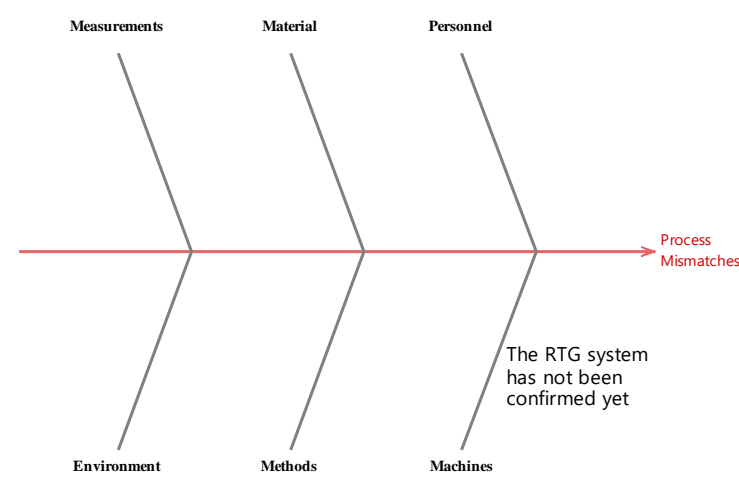

Figure 13. Fishbone Fourth of Process

Figure 13 explains the cause of the non-conformity of the fourth process, namely the process of the gate operator to confirm. It can be seen that the cause of this is due to the RTG system which has not confirmed that the containers have been moved. So the system refuses the containers to come out. Here is a diagram of fishbone Process five.

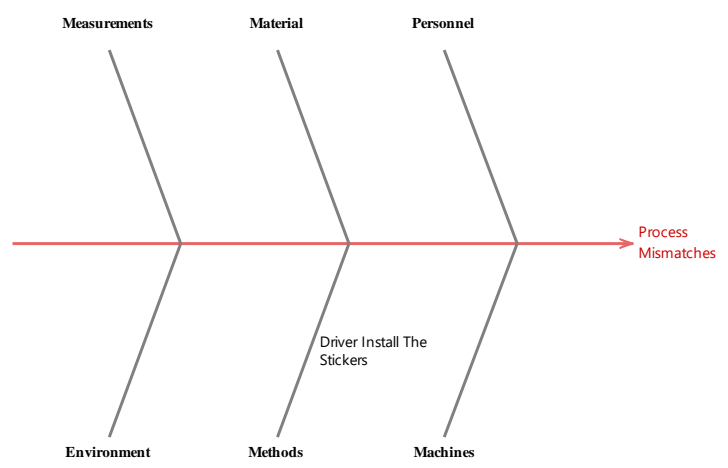

Figure 14. Fishbone Fifth Process

Figure 14 explains the cause of the inadequacy of the fifth process, namely the process of the gate operator to confirm. It can be seen that the cause that occurred could be caused by the driver who got off and put up a Customs sticker that was not installed. Here is a diagram of the sixth process fishbone.

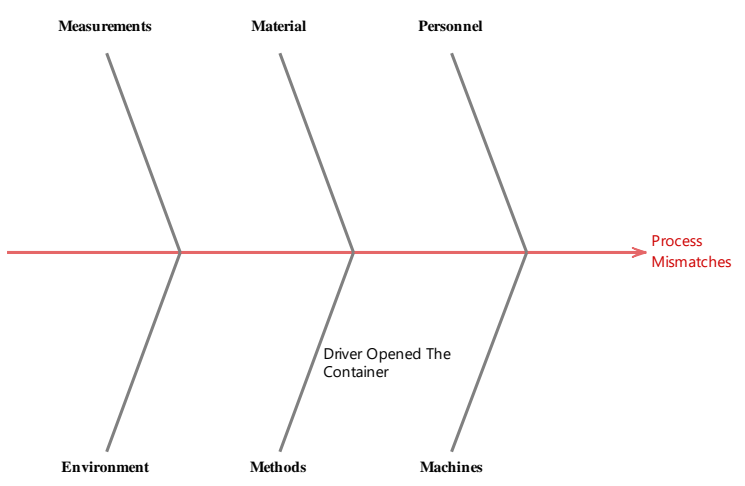

Figure 15. Fishbone Sixth Process

Figure 15 explains the cause of the non-conformity of the sixth process, namely the process of trucks leaving the gate. It can be seen that the cause that occurs can be caused by a driver who has dropped to open a container that has an MTY status.

\subsection{Fishbone Diagram of Service Process Per Season}

Fishbod diagram is used to find out the cause of the mismatch for each season. Here is the fishbone of each season on the import Gate Out service during the observation.

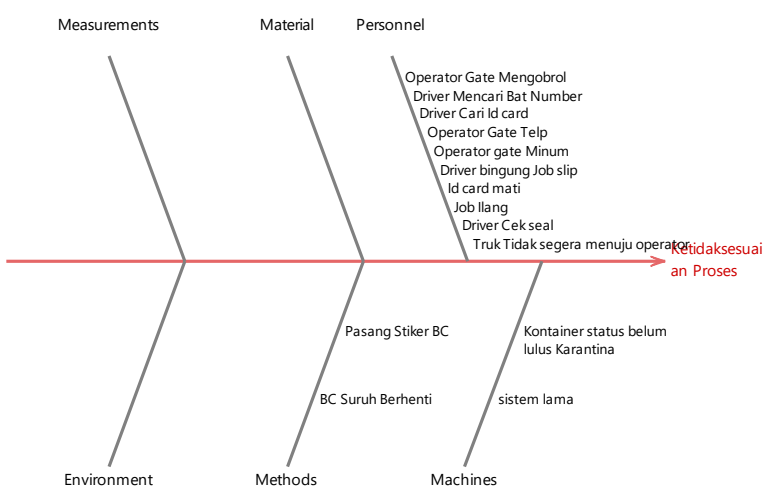

Figure 16. Fishbone of Low Season Process

Figure 16, it can be seen that the causes of process mismatches in low season tend to occur due to personal, where what is meant by personal here is caused by the driver itself and the gate operator in providing services.

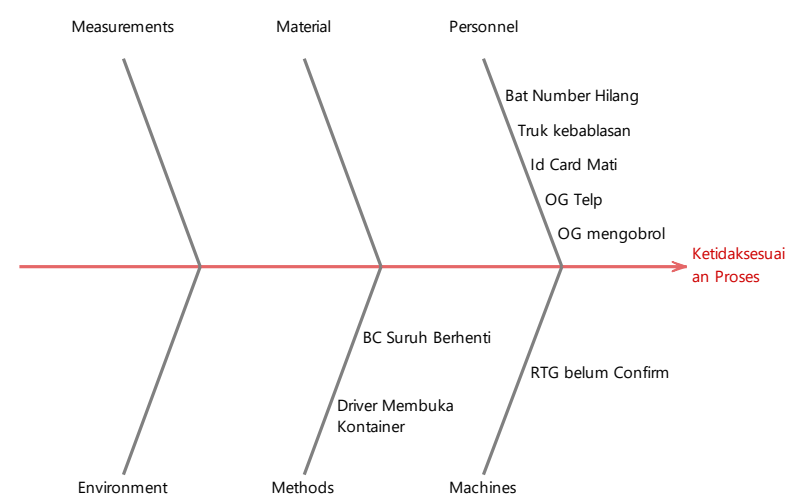

Figure 17. Fishbone of Low Season Process

Figure 17 describes the process mismatch in Peak season. It can be seen that the causes of these causes tend to be personal, namely the driver itself and the gate operator.

\section{CONCLUSIONS}

\subsection{Conclusion}

The conclusion is the main point of the research result. Based on the results of the analysis in the previous chapter, several things can be concluded.

1. The average processing time per day observed tends to have the same pattern.

2. The average overall processing time is 33 seconds per transaction.

3. The average time of each process per season has an average difference of 2 seconds of processing and tends to have the same pattern.

4. Analysis using the $\mathrm{S}$ control chart shows that the process has been controlled statistically and X-S control chart shows that the process has not been controlled statistically. The results of the process capability analysis show that the process is not capable as evidenced by the $\mathrm{cp}$ and cpk values that are less than one. And based on the process, it was 
found that the most mismatches occurred in the second process and the mismatches based on season were found to tend to occur due to drivers and operators.

\subsection{Recommendation}

The reccomendation that can be given by researchers to improve the productivity performance of gate operators by tightening existing SOPs and conducting regular supervision every day for the smooth running of the service process. And can do further information or socialization related to the latest regulatory updates and involving drivers.

\section{ACKNOWLEDGEMENT}

Rafly, as the author, expresses his gratitude on His guidance and grace, so that he could complete the internship report. The author also really appreciate the help, motivation, and support from various parties, either directly or indirectly. Therefore, the author would like to thank the supervisors at PT Terminal Petikemas Surabaya, the supervisors and the Business Statistics Department as well as friends and all people who gave me their enthusiasm. Hopefully, this report can be useful and used as a good reference in the future.

\section{REFERENCES}

[1] E. Supardi, "Ekspor Impor: Teori Dan Praktikum Kegiatan Ekspor Impor Untuk Praktisi Logistik Dan Bisnis," Sleman: Deepublish 2019.

[2] R. E. Walpole, "Introduction to statistics III,". New York: Macmillan, 1982.

[3] J. Salim, "Cara Gampang Bermain Saham," Jakarta: Visimedia 2010

[4] D. C. Montgomery, "Introduction to statistical Quality control III," vol. 2, Hoboken, NJ: Wiley, 2020.

[5] W. Daniel, "Statistika Non Parametrik Terapan II," Jakarta: PT. Gramedia Pustaka Utama, 1989.

[6] M. Ratnasari, "Dampak Sosial Ekonomi Revitalisasi Pasar Tradisional Bagi Pedagang Di Kota Semarang," Economics Development Analysis Journal, vol. 6, no. 2, pp. 215-220, 2018.

[7] S. L. Tubbs and S. Moss, "Human communication," 4th ed New York: Random House, 1983.

[8] Sugiyono, "Metode Penelitian Kuantitatif. Bandung: PT Alfabet, 2017. 